\title{
Development and validation of a simple and sensitive HPLC method for the determination of liquid form of therapeutic substances
}

\author{
Suhaib Ibrahim Alkhamaisah, Kareem M. Younes ${ }^{2}$, Abduzhappar Gaipov ${ }^{3}$, Mohamad Aljofan ${ }^{4}$
}

\begin{abstract}
Background: Caffeine is the most consumed psychostimulant in the world that is found in numerous foods and drinks with coffee and tea have the highest concentration of caffeine per weight. Caffeine has a number of reported physiological benefits and clinical uses such as coma recovery. Caffeine can prove dangerous and its consumption, the amount in foods and drinks should be closely monitored, by the Food and Drug Administration.

Material and Methods: The availability of sensitive, reliable, and simple testing methods with rapid turnover time is essential for testing any laboratories. In this manuscript, we describe the development and validation of a simple, sensitive and economical high performance liquid chromatographic (HPLC) method with ultraviolet detection for the quantification of the amount of caffeine in different beverages.

Results: HPLC method was validated and tested to measure caffeine contents in different beverages that showed high precision, reliability, and sensitivity that makes it suitable for routine measurement of caffeine as well as other therapeutic or chemicals in liquid forms.

Conclusions: The proposed method recovered caffeine without the need for any extraction step for recovering the caffeine from the formulation excipients matrices, therefore decreased the degree of error, time for estimation of caffeine and the overall cost of the analysis.
\end{abstract}

Keywords: caffeine, coffee, extraction, HPLC, PDA

\section{INTRODUCTION}

Caffeine (1,3,7-tryethylxanthine) is known as a purine alkaloide that occurs naturally in many plants particularly in Coffea arabica, Coffea robusta and Camellia sinensis (Figure 1) (1). Caffeine has a psychoactive effect and it appeared to exert most of its biological activity through the antagonism of the adenosine receptor, which is an endogenous inhibitory neuromodelator that promotes feeling of drowsiness $(2,3)$. Caffeine is the most consumed pharmacological agent worldwide that is traditionally used to improve mental alertness, concentration, fatigue, and athletic performance $(4,5)$. Clinically, it is widely used for the treatment of neurasthenia and the recovery of coma $(6,7)$. Other reported uses include weight loss (8), improved glucose tolerance (9) and lower risk of type II diabetes (10), reduced risk for incidence of Parkinson's disease and improvement in Parkinson's symptoms, and reduced risk for cancer at several sites (11). Caffeine is playing an important role in inhibition reparation of DNA double-strand breaks in HeLa cells and ataxia telangiectasia mutated and ataxia telangiectasia mutated-related in DNA damage response pathway in breast cancer cell lines $(12,13)$. Previously, we demonstrated that caffeine can inhibit viral infection and replication in vitro $(14,15)$.

Furthermore, caffeine decreases the secretion of the pro-inflammatory cytokines interleukin-1 receptor antagonist and interleukin-10 receptor by cancer cell-stimulated peripheral blood mononuclear cells (16). Also, it is considered as chemopreventive and anti-inflammatory agent where it is protective agent against cirrhosis and hepatic fibrosis, two chronic inflammatory diseases that can lead to liver cancer development $(17,18)$.

\footnotetext{
1 Department of Pharmaceutical Chemistry; College of Pharmacy, Jerash University, the Hashemite Kingdom of Jordan.

2 Department of Pharmaceutical Chemistry; College of Pharmacy, Hail University, Hail, Saudi Arabia.

3 Department of Clinical Science, Nazarbayev University School of Medicine, NurSultan, Kazakhstan.

4 Department of Biomedical Science, Nazarbayev University School of Medicine, NurSultan, Kazakhstan.
}

Correspondence: Mohamad Aljofan

Department of Biomedical Science, Nazarbayev University School of Medicine, NurSultan, Kazakhstan.

E-mail:m.aljofan@gmail.com

Received: 30 Jul 2019, Accepted: 11 Sep 2019

(C) 2019 by the authors; licensee Modestum Ltd., UK. This article is an open access article distributed under the terms and conditions of the Creative Commons Attribution License (http://creativecommons.org/licenses/by/4.0/). 
<smiles>Cn1c(=O)c2c(ncn2C)n(C)c1=O</smiles>

Figure 1: Chemical structure of Caffeine

Approximately, caffeine is found in the leaves, seeds, or fruits of over 63 plant species (6) with the highest contents per source was found in coffee beans (19). However, the amount of recoverable caffeine from the different sources is influenced by a number of factors including preparation processes such as fermentation and roasting (20). Therefore, accurate measurement of the recoverable amounts will enable us to increase the availability of the natural occurring substance.

Therefore, we developed and validated a sensitive high performance liquid chromatographic (HPLC) method with ultraviolet detection to measure the amount of caffeine in different beverages and to compare the caffeine yields from each preparation.

The developed method, which is amenable to use to measure other substances in liquid including biologics, employs RP- Thermo C18 column, $(4.6 \times 150 \mathrm{~mm}, 5 \mu \mathrm{m}$ id) with flow rate of $1.0 \mathrm{ml} / \mathrm{min}$ using PDA detector at $254 \mathrm{~nm}$ and.

\section{METHODS}

\section{Apparatus}

The HPLC chromatograms were obtained using a Shimadzu instrument, Model LC-10 ADVP, equipped with a variable wavelength UV-visible detector, Model SPD-10 AD VP, Degasser Model DGU-12 A and a 20- $\mu$ l volume Rheodyne injector. RP-Thermo C18 $(5 \mu \mathrm{m}, 250 \mathrm{~mm} \times 4.6 \mathrm{~mm}$ I.D) column was used as a stationary phase.

\section{Materials}

\section{Samples}

Caffeine standard (B.N: 08209B5-012) was purchased from Aldrich, Germany. Its purity was found to be $99.0 \pm 0.26$, according to its official procedures (21). Caffeine containing products such as green/ brown/ black coffee, green/ black/ tea, and soft/ energy drinks.

\section{Chemicals}

All chemicals and reagents were of pure analytical grade. De-ionized water, Acetonitrile, Methanol (E-Merck, Darmstadt, Germany) was of HPLC grade.

\section{Caffeine stock and working solutions}

Accurately weighed $100 \mathrm{mg}$ of caffeine powder was transferred into $100-\mathrm{ml}$ measuring flask. $50.0 \mathrm{ml}$ of de-ionized water was added to the flask, sonicated for a while to dissolve the drug. The flask was made up to $100 \mathrm{ml}$ with de-ionized water to get a final concentration of $1000 \mu \mathrm{g} / \mathrm{ml}$. Caffeine working standard solution was prepared by accurately transferring $25-\mathrm{ml}$ of the stock solution $(1000 \mu \mathrm{g} / \mathrm{ml})$ into $100-\mathrm{ml}$ measuring flask and then was diluted with water to a final concentration of $250 \mu \mathrm{g} / \mathrm{ml}$.

\section{Chromatographic conditions}

The stationary phase used is C-18 RP-Thermo, $5 \mu \mathrm{m}, 250 \mathrm{~mm} \times 4.6 \mathrm{~mm}$ column. A low gradient mobile phase containing water, methanol and acetonitrile in a ratio of $84: 1: 15(\mathrm{v} / \mathrm{v} / \mathrm{v})$ was filtered using $0.45 \mu \mathrm{m}$ filter paper. The flow rate was $1.0 \mathrm{ml} / \mathrm{min}$ and the detection was done using PDA detector at $254 \mathrm{~nm}$. The mobile phase was degassed for about 15 min by sonication and samples of $20 \mu$ l were injected into the HPLC system where a sharp peak was obtained. 


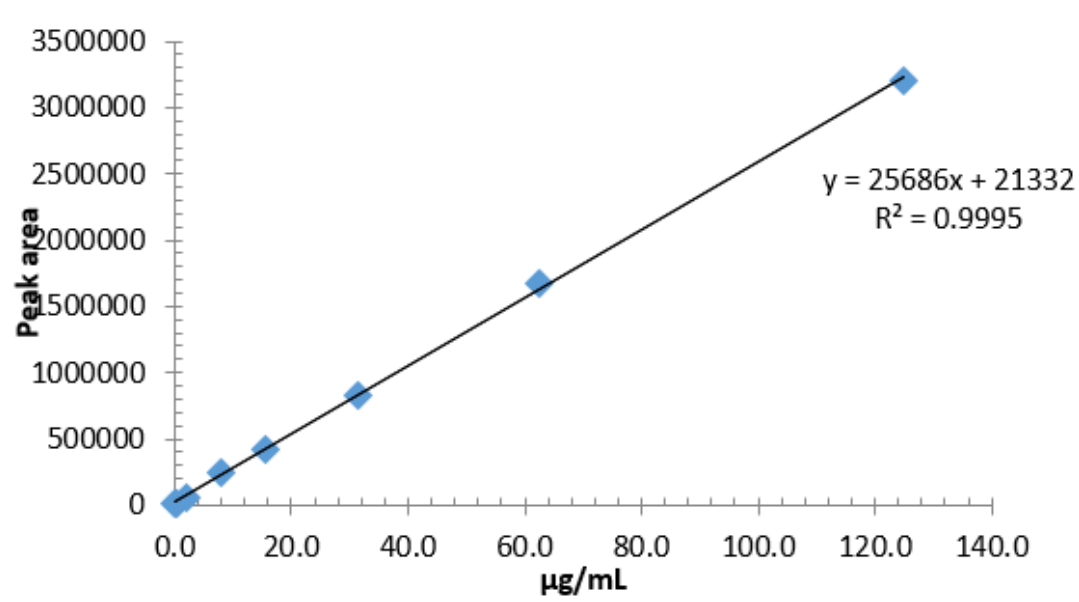

Figure 2: Caffeine calibration curve

Table 1: Linearity and regression characteristics of standard caffeine

\begin{tabular}{cc}
\hline Parameter & Caffeine \\
\hline Concentration range $(\mu \mathrm{g} / \mathrm{ml})$ & $0.122-125$ \\
\hline Regression equation & $\mathrm{Y}=25686 \mathrm{X}+21332$ \\
\hline Slope & 25686 \\
\hline Intercept & 21332 \\
\hline $\mathrm{N}$ & 0.9995 \\
\hline $\mathrm{LOD}(\mu \mathrm{g} / \mathrm{ml})$ & 8 \\
\hline $\mathrm{LOQ}(\mu \mathrm{g} / \mathrm{ml})$ & 0.0091 \\
\hline
\end{tabular}

\section{Procedures}

\section{Construction of calibration curve}

Five different concentrations that ranged from 7.813 to $125 \mu \mathrm{g} / \mathrm{ml}$ were prepared by accurately measuring different volumes of working caffeine standard solutions $(250 \mu \mathrm{g} / \mathrm{ml})$. The prepared series of caffeine were injected into the chromatographic system and the peak area for each concentration was recorded. The relation between the concentration and the peak area was plotted and the regression equation was calculated (Figure 2).

\section{Sample Analyses}

Sample preparation represents one of the most important steps in analysis (22), thus samples from solid sources (coffee beans or tea leaves) were carefully prepared as follows: a $100 \mathrm{~g}$ of green, brown, black or instant coffee, and 10 $\mathrm{g}$ of black tea were accurately weighed and finely powdered. Caffeine was extracted by boiling with water for 10 minutes, then transferred into a separating funnel, and placed on shaker with $25 \mathrm{ml}$ of Dichloromethane twice. Organic phase was collected in round bottom flask and condensed using rotary evaporator. Preparation of liquid samples from were performed by separately measuring $100-\mathrm{ml}$ of soft and energy drinks and directly transferring them into a separating funnel. We carried out an extraction with $25-\mathrm{ml}$ of dichloromethane twice and collected the organic phase in round bottom flask. The residue obtained from both solid and liquid sources were then transferred into $100-\mathrm{ml}$ measuring flask and completed to volume with de-ionized water.

\section{Method Validation and Parameters}

The newly developed RP-HPLC method was validated as per International Conference on Harmonization (ICH) parameters like system suitability, linearity and range, precision, accuracy, LOD and robustness (23). The linearity of the method was studied by injecting the concentrations of the standard solution prepared in the mobile phase in the range of $(0.122-125) \mu \mathrm{g} / \mathrm{mL}$ for caffeine; in triplicate into the HPLC system keeping the injection volume constant. The peak areas were plotted against the corresponding concentrations to obtain the calibration curves (Table 1).

The sensitivity of the proposed method was estimated in terms of Limit of Detection (LOD) and Limit of Quantification (LOQ) (24). $L O D=3 \mathrm{SD} / \mathrm{S}$ and $\mathrm{LOQ}=10 \mathrm{SD} / \mathrm{S}$, where S.D. is the standard deviation of $y$-intercept and $\mathrm{S}$ is the slope of the line (25) as shown in Table 1. Also, we tested the accuracy of the method by preparing recovery samples containing 
Table 2: Percentage recovery of Caffeine

\begin{tabular}{|c|c|c|c|}
\hline & Amount added $(\mu \mathrm{g} / \mathrm{ml})$ & Amount found ( $\mu \mathrm{g} / \mathrm{ml})$ & Recovery \% \\
\hline & 26.73 & 26.00 & 97.30 \\
\hline \multirow[t]{2}{*}{ Caffeine } & 53.94 & 53.00 & 98.30 \\
\hline & 111.00 & 108.61 & 98.00 \\
\hline
\end{tabular}

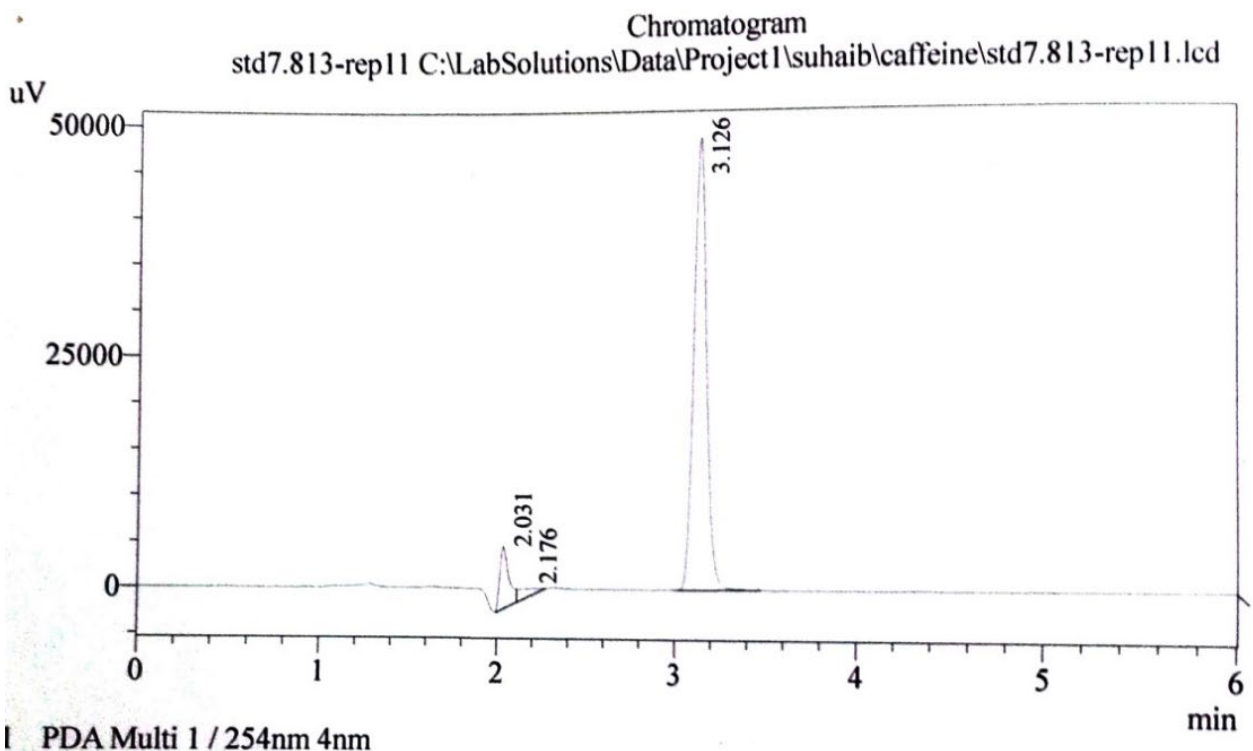

I PDA Multi $1 / 254 \mathrm{~nm} 4 \mathrm{~nm}$

Figure 3: HPLC Chromatogram of Caffeine

different known quantities of caffeine standard. Each sample was prepared in triplicate and then all samples were injected into the HPLC system and the percentage recovery for the amount added was estimated.

\section{Intra-day and Inter-day Precision}

While intra-day precision were determined by estimating the \% RSD of the peak area for three replicate injections of three standard solutions in different occasions in same day, inter-day precision were estimated by assessing the \% RSD of the peak area for three replicate injections of three standard solutions in three consecutive days.

Furthermore, the specificity of the method was assessed by comparing chromatogram obtained from standard caffeine with that from marketed solutions (26). To estimate the system's suitability parameters, a standard solution of caffeine was injected into the HPLC system using mobile phase solvents of different ratios (80/5/15, 85/5/10, 75/10/15, $84 / 1 / 15$ and 80/1/19) and a standard solution of caffeine was injected into the HPLC system using different C8 and C18 columns, results are shown in Table 5 and $\mathbf{6}$, respectively. The effect of mobile phase flow rate variation was investigated by injecting a standard solution of caffeine into the HPLC system using different flow rate values ranging from 0.5 to 2 $\mathrm{ml} / \mathrm{min}$, Table 7.

\section{RESULTS AND DISCUSSION}

The HPLC method with diode array detection developed for the quantitative determination of caffeine from different liquid sources and compared to that from solid, which provided a stable retention times and a detection limit of 0.01 $\mathrm{mg} / \mathrm{L}$ for a signal-to-noise ratio of 3 (Figure 3). Different columns and mobile phase ratios were tried and good results were obtained using RP-Thermo $\mathrm{C} 18(5 \mu \mathrm{m}, 250 \mathrm{~mm} \times 4.6 \mathrm{~mm})$ column and acetonitrile: water: methanol in a ratio of $(15: 1: 84, v / v / v)$ as a mobile phase. Caffeine was detected by using PDA detector at $254 \mathrm{~nm}$. The method was validated in terms of linearity, range, specificity, precision, accuracy and robustness. The mean recovery of caffeine was $97.87 \%$ as shown in Table 2 with a calibration curve and linearity study of caffeine showed good correlation coefficient in concentration range of $(0.122-125.0) \mu \mathrm{g} / \mathrm{mL}$ with an $R^{2}$ value of greater than 0.9995 . The detector response over a wide range of concentrations of the analyte were plotted to obtain the calibration curve on Figure $\mathbf{2}$, and the value for $R^{2}$ and equation for the curve is shown in Table 1. Based on previously published studies, it is acceptable to use a single point calibration in analysis of actual samples (27).

Furthermore, the accuracy of the method was confirmed by studying sample recovery using three different concentrations for each sample in triplicates $(n=3)$. Samples of known concentration (reference standard solutions) were 
Table 3: Precision of standard Caffeine

\begin{tabular}{|c|c|c|c|}
\hline & Amount added $(\mu \mathrm{g} / \mathrm{ml})$ & R.S.D \% (Intra-day) & E \% \\
\hline \multirow{5}{*}{ Caffeine } & 26.73 & 0.022 & 1.93 \\
\hline & 53.94 & 0.128 & 1.41 \\
\hline & 111.00 & 0.037 & 0.67 \\
\hline & Amount added $(\mu \mathrm{g} / \mathrm{ml})$ & R.S.D \% (Inter-day) & E \% \\
\hline & 26.00 & 0.115 & 1.87 \\
\hline \multirow[t]{2}{*}{ Caffeine } & 53.00 & 0.154 & 1.52 \\
\hline & 111.00 & 0.921 & 0.81 \\
\hline
\end{tabular}

Table 4: Specificity of proposed HPLC method for Caffeine

\begin{tabular}{cl}
\hline Pure CAF / CAF preparation & $\mathbf{t}_{\mathbf{R}}(\mathbf{m i n})$ \\
\hline Standard CAF & 3.127 \\
\hline Black tea & 3.091 \\
\hline Green tea & 3.146 \\
\hline Black Coffee & 3.147 \\
\hline Brown Coffee & 3.129 \\
\hline Green Coffee & 3.132 \\
\hline Nescafe & 3.125 \\
\hline Pepsi & 3.155 \\
\hline Pepsi Diet & 3.126 \\
\hline Mountain Dew & 3.132 \\
\hline Red Bull & 3.124 \\
\hline
\end{tabular}

Table 5: Effect of mobile phase ratio on separation of standard Caffeine

\begin{tabular}{|c|c|c|}
\hline \multirow{2}{*}{ Mobile phase ratio } & \multicolumn{2}{|c|}{ Caffeine } \\
\hline & Area & $t_{R}$ (min) \\
\hline $80 / 5 / 15$ & 417645 & 3.265 \\
\hline $85 / 5 / 10$ & 242177 & 3.332 \\
\hline $75 / 10 / 15$ & 16048 & 3.421 \\
\hline $84 / 1 / 15$ & 708313 & 3.127 \\
\hline $80 / 1 / 19$ & 417645 & 3.233 \\
\hline
\end{tabular}

Table 6: Effect of column type on separation of standard Caffeine

\begin{tabular}{|c|c|c|}
\hline \multirow{2}{*}{ Column type } & \multicolumn{2}{|c|}{ Caffeine } \\
\hline & Area & $t_{R}(\min )$ \\
\hline C8 column & 117645 & 4.321 \\
\hline C 18 Lichrosphere & 212388 & 3.311 \\
\hline C 18 waters & 510211 & 3.221 \\
\hline C 18 Thermo & 708313 & 3.127 \\
\hline C 18 Zorbax & 417645 & 3.309 \\
\hline
\end{tabular}

analyzed and the measured values, from the respective area counts, were compared with the true values. The results obtained from the determination of accuracy, expressed as percentage recovery (Table 2), which shows that the method was able to accurately quantify an estimation of caffeine and that all the results were within acceptable limit of measurement (28). Interestingly, the evaluation of the precision that was performed using 3 different sample preparations showed a significantly high percentage of precision (Table 3) with percentage relative standard deviation (RSD \%) was found to be less than 1, and E\% less than 2 which proves that the developed method is precise and reproducible (30).

However, the specificity was evaluated by estimating the retention time of caffeine in pure and the investigational samples from both solid and liquid sources. There was no difference in the retention time between the standard and the investigational samples, either solid or liquid forms (Table 4). The results of limit of detection and limit of quantification are illustrated in Table 1.

The robustness of the method was measured via determining the effect of the mobile phase ratio variation, column variation and flow rate variation. Both of the selected mobile phase ratio of 84: 1: $15(\mathrm{v} / \mathrm{v} / \mathrm{v})($ Table 5) and column variation, C $18 \mathrm{RP}$-Thermo,5 $\mu \mathrm{m}, 250 \mathrm{~mm} \times 4.6 \mathrm{~mm}$ (Table 6), resulted in a good peak shape (Table 5), acceptable back pressure and good resolution. Also, flow rate $1 \mathrm{~mL} / \mathrm{min}$, which was selected because of less retention time resulted in a significantly better separation of the analyte (Table 7). 
Table 7: Effect of mobile phase flow rate on separation of standard Caffeine

\begin{tabular}{|c|c|c|}
\hline \multirow{2}{*}{ Flow rate $(\mathrm{ml} / \mathrm{min})$} & \multicolumn{2}{|c|}{ Caffeine } \\
\hline & Area & $t_{R}(\mathrm{~min})$ \\
\hline 0.5 & 542139 & 3.421 \\
\hline 0.8 & 644317 & 3.261 \\
\hline 1.0 & 708313 & 3.127 \\
\hline 1.5 & 502114 & 3.031 \\
\hline 2.0 & 337215 & 2.945 \\
\hline
\end{tabular}

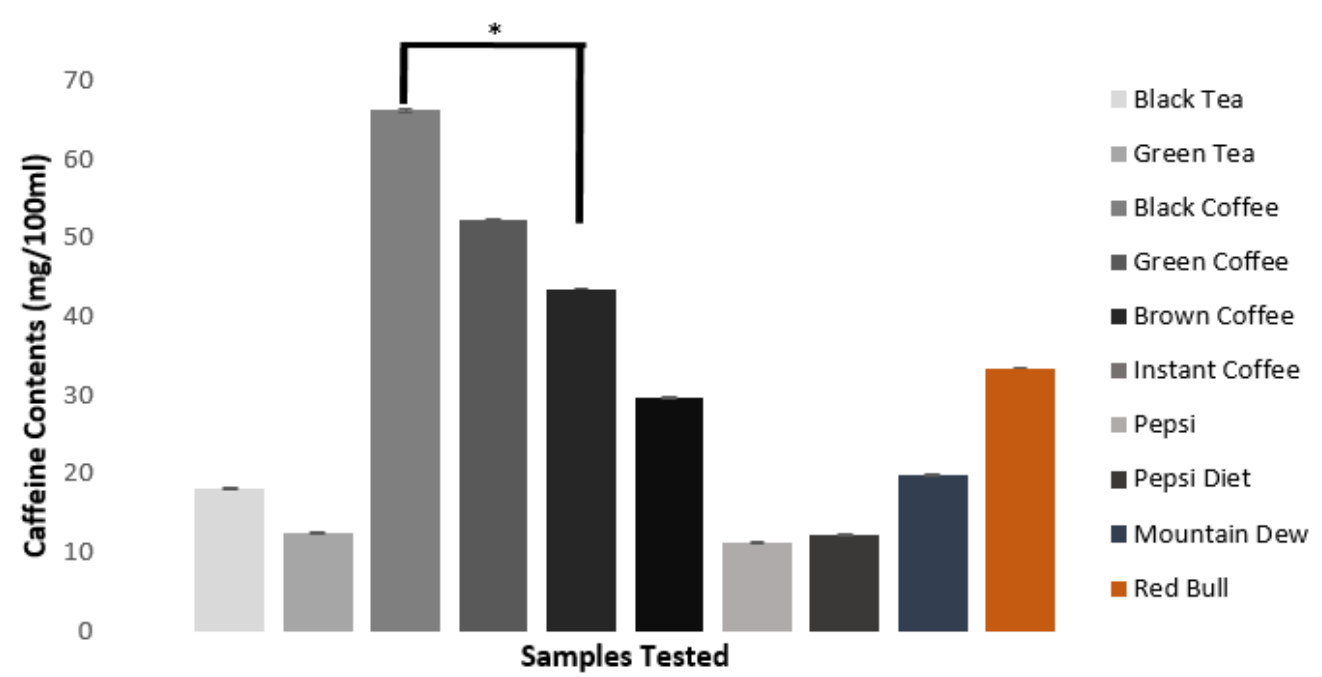

Figure 4: Percentage of caffeine recovered from investigational samples

Nonetheless, the method was successfully applied to measure caffeine contents from different and commonly used beverages including, coffee (different preparations), tea (green and black) as well as several soft drinks (Figure 4). Our results indicated that roasting of coffee beans can significantly affect the amount of caffeine found, for example there was a significant difference in the caffeine amount recovered between black and green (raw) coffee beans as well as between black and green tea (Figure 4). These findings are supported by a number of previously published findings that suggested that caffeine amount depends on the preparation and extraction of the beans $(2,24)$. Furthermore, Angeloni et al., reported that the chemical composition of brewed coffee depends on numerous factors: the beans, post-harvest processing and, finally, the extraction method (31). Interestingly, there was no difference between the amount of caffeine recovered from instant coffee and that of energy drinks and that regardless of preparation methodology used, coffee beans (black, brown or green) were shown to have significantly more caffeine contents than energy drinks (Figure 4). These findings are demonstrate that roasted beans have significantly higher amount of caffeine than non-roasted or raw and that a cup of coffee could potentially have more caffeine contents than a can of energy drink.

The graph above shows the amount of caffeine recovered from the investigational samples. The results indicate that sample preparation plays an important role that can significantly affect the amount of caffeine yielded $\left(^{\star}\right)$ represent significance.

\section{CONCLUSION}

The current study describes the development and validation of a reversed-phase HPLC with PDA detection method for the determination of substances from different liquid sources. In this example we used caffeine measurements from coffee, tea and soft drinks. This is a simple, economical method with a broad detection and quantification limits that produced good resolution for caffeine with a short analysis time in less than 3.5 minutes.

The proposed method recovered caffeine with precision without the need for any extraction step for recovering the caffeine from the formulation excipients matrices, therefore decreased the degree of error, time for estimation of caffeine and the overall cost of the analysis.

Finally, the rapidity and capability of quantifying low concentrations of caffeine, makes the method suitable for variety of analyses, including pure drug analysis and assay of formulations analysis as well as its suitability in a quality control laboratory for routine sample analysis. 


\section{REFERENCES}

1. Spiller MA. The chemical components of coffee. Prog Clin Biol Res, 1984;158:91-147.

2. Higdon JV, Frei B. Coffee and health: a review of recent human research. Crit Rev Food Sci Nutr, 2006;46(2):10123. https://doi.org/10.1080/10408390500400009 PMid: 16507475

3. Paule $S$, et al. Cleavage of endometrial alpha-integrins into their functional forms is mediated by proprotein convertase 5/6. Hum Reprod, 2012;27(9):2766-74. https://doi.org/10.1093/humrep/des203 PMid:22740495

4. Cronstein BN. Caffeine, a drug for all seasons. J Hepatol, 2010;53(1):207-8. https://doi.org/10.1016/j.jhep.2010.02.025 PMid:20452698 PMCid:PMC2891534

5. Ballard SL, Wellborn-Kim JJ. Effects of Commercial Energy Drink Consumption on Athletic Performance and Body Composition. The Physician and Sports medicine Journal, 2010;38:107-17.

6. Sereshti $\mathrm{H}$, Samadi S. A rapid and simple determination of caffeine in teas, coffees and eight beverages. Food Chem, 2014;158:8-13. https://doi.org/10.1016/j.foodchem.2014.02.095 PMid:24731307

7. Guo $S$, et al. Determination of caffeine content in tea based on poly (safranine T) electroactive film modified electrode. Food Chem, 2011;129(3):1311-4. https://doi.org/10.1016/j.foodchem.2011.05.095 PMid:25212372

8. Modi $A A$, et al. Increased caffeine consumption is associated with reduced hepatic fibrosis. Hepatology, 2010;51(1):201-9. https://doi.org/10.1002/hep.23279 PMid:20034049 PMCid:PMC2801884

9. Strassnig M, Brar JS, Ganguli R. Increased caffeine and nicotine consumption in community-dwelling patients with schizophrenia. Schizophr Res, 2006;86(1-3):269-75. https://doi.org/10.1016/j.schres.2006.05.013 PMid:16859897

10. Aljofan M, Gaipov A. Metformin: A stroke of luck. . Electronic Journal of General Medicine, 2019;16(3):em143. https://doi.org/10.29333/ejgm/108679

11. de Oliveira PF, et al. Bixin protects hepatocytes against 1,2-dimethylhydrazine-induced genotoxicity but does not suppress DNA damage and pre-neoplastic lesions in the colon of Wistar rats. Mutat Res Genet Toxicol Environ Mutagen, 2014;759:37-42. https://doi.org/10.1016/j.mrgentox.2013.07.017 PMid:24246722

12. Tsabar $M$, et al. Caffeine impairs resection during DNA break repair by reducing the levels of nucleases Sae2 and Dna2. Nucleic Acids Res, 2015;43(14):6889-901. https://doi.org/10.1093/nar/gkv520 PMid:26019182 PMCid:PMC4538808

13. Alao JP, Sunnerhagen P. The ATM and ATR inhibitors CGK733 and caffeine suppress cyclin D1 levels and inhibit cell proliferation. Radiat Oncol, 2009;4:51. https://doi.org/10.1186/1748-717X-4-51 PMid:19903334 PMCid:PMC2777912

14. Aljofan $\mathrm{M}$, et al. Off Label Antiviral Therapeutics for Henipaviruses: New Light through Old Windows. J Antivir Antiretrovir, 2010;2(1):1-10.

15. Aljofan $M$, et al. Antiviral activity of gliotoxin, gentian violet and brilliant green against Nipah and Hendra virus in vitro. Virol J, 2009;6:187. https://doi.org/10.1186/1743-422X-6-187 PMid:19889218 PMCid:PMC2781006

16. Bessler $\mathrm{H}$, et al. Caffeine alters cytokine secretion by PBMC induced by colon cancer cells. Cancer Invest, 2012;30(2):87-91. https://doi.org/10.3109/07357907.2011.636113 PMid:22149008

17. Cornelis $\mathrm{MC}$, et al. Genome-wide meta-analysis identifies six novel loci associated with habitual coffee consumption. Mol Psychiatry, 2015;20(5):647-56. https://doi.org/10.1038/mp.2014.107 PMid:25288136 PMCid:PMC4388784

18. Sumi T, et al. (-)-Epigallocatechin-3-gallate suppresses hepatic preneoplastic lesions developed in a novel rat model of non-alcoholic steatohepatitis. Springerplus, 2013;2:690. https://doi.org/10.1186/2193-1801-2-690 PMid:25674420 PMCid:PMC4320203

19. Spiller MA. The coffee plant and its processing. Prog Clin Biol Res, 1984;158:75-89.

20. Petrick JL, et al. Coffee Consumption and Risk of Hepatocellular Carcinoma and Intrahepatic Cholangiocarcinoma by Sex: The Liver Cancer Pooling Project. Cancer Epidemiol Biomarkers Prev, 2015;24(9):1398-406. https://doi.org/10.1158/1055-9965.EPI-15-0137 PMid:26126626 PMCid:PMC4576990

21. Pharmacopoeia TUS. (USP XXIX, National Formulary (NF24). The United States Pharmacopeial Convention, Inc. Rockville. 2007:1168.

22. Alshammari TM, et al. Comparison of different serum sample extraction methods and their suitability for mass spectrometry analysis. Saudi Pharm J, 2015;23(6):689-97. https://doi.org/10.1016/j.jsps.2015.01.023 PMid:26702265 PMCid:PMC4669428 
23. Aljofan $M$, et al. Development and validation of a chemiluminescent immunodetection assay amenable to high throughput screening of antiviral drugs for Nipah and Hendra virus. J Virol Methods, 2008;149(1):12-9. https://doi.org/10.1016/j.jviromet.2008.01.016 PMid:18313148 PMCid:PMC2653211

24. Ali MM, Eisa M, Taha MI, Zakaria BA, Elbashir AA. Determination of Caffeine in Some Sudanese Beverages by High Performance Liquid Chromatography. Pakistan Journal of Nutrition, 2012:11(4):336-337. https://doi.org/10.3923/pjn.2012.336.342

25. Ojha A, Rathod R, Padh H. Simultaneous HPLC-UV determination of rhein and aceclofenac in human plasma. J Chromatogr B Analyt Technol Biomed Life Sci, 2009;877(11-12):1145-8. https://doi.org/10.1016/j.jchromb.2009.02.061 PMid:19299212

26. Nour V, Ion T, Elena IM. Chromatographic Determination of Caffine Contents in soft and and Energy Drinks Available on The Romanian Market. Scientific Study and Research: Chemistry and Chemical Engineering, 2010;11(3):351-3.

27. Ebrahimzadeh $\mathrm{H}$, et al. Simultaneous determination of chloropheniramine maleate and dextromethorphan hydrobromide in plasma sample by hollow fiber liquid phase microextraction and high performance liquid chromatography with the aid of chemometrics. Talanta, 2012;94:77-83. https://doi.org/10.1016/j.talanta.2012.02.054 PMid:22608417

28. Snyder LR, Kirkland JJ, Dolan JW. Introduction to modern liquid chromatography. Third Edition ed. 2010: A John Wiley \& Sons, Inc. https://doi.org/10.1002/9780470508183

29. Snyder LR, Kirkland JJ, Glajch JL. Practical HPLC Method Development, Second Edition ed. 1997: A John Wiley \& Sons, Inc.

30. Hornedonunez A, Getek TA, Korfmacher WA, Simenthal F. High-performance liquid-chromatography of clindamycin and clindamycin phosphate with electrochemical detection. Journal of Chromatography, 1990;503:217-25. https://doi.org/10.1016/S0021-9673(01)81503-X

31. Angeloni $G$, et al. What kind of coffee do you drink? An investigation on effects of eight different extraction methods. Food Res Int, 2019;116:1327-35. https://doi.org/10.1016/j.foodres.2018.10.022 PMid:30716922

$\diamond \diamond \diamond \diamond \diamond \diamond \diamond$

http://www.ejgm.co.uk 